\title{
Effect of perceived default risk and accounting information quality on the decision to grant credit to SMEs
}

\begin{abstract}
The present study analyses the influence that perceived default risk and accounting information quality have on the process of credit granting to SMEs. Empirical evidence was obtained from a survey of 471 bank loan officers in Spain, in which they were asked to answer questions relating to audited and not-audited firms. Through a Structural Equations Modeling (SEM) approach, the results confirm that the likelihood that the loan officers are more willing to provide access to credit to SMEs, and to do so in more favourable conditions, is negatively influenced by perceived default risk and positively influenced by the general perception about accounting information quality. Besides, we find that information quality is an antecedent of perceived risk, so that the latter becomes the central element of the research model. Additionally, the perceptions of the decision-makers regarding all the analysed variables are better for the audited SMEs than for the unaudited ones.
\end{abstract}

Key words: Perceived risk, information quality, credit access, credit conditions, external audit, SMEs. 


\section{Introduction}

The availability of bank financing for small and medium-size enterprises (SMEs) is a topic of significant research interest among academics and a crucial issue for policymakers (Berger and Udell, 2006; De la Torre et al, 2010). This interest is driven in part by the fact that SMEs play a key role in the creation of wealth and employment of any economy. In addition, banks are the main source of finance for small firms (Cosh and Hughes, 1994).

Regardless, a number of papers find that SMEs are more financially constrained than large firms, so they frequently experience problems obtaining both their required levels of bank financing and sufficiently favourable conditions of borrowing (see, among others, Cressy, 2002; Beck et al, 2005, 2006). One of the often-cited main factors that hampers SMEs financing is opaqueness, which accentuates information asymmetries (Berger and Udell, 1998; Berger et al, 2001; Hyytinen and Pajarinen, 2008). In the literature, "opaqueness" is often referred to the greater difficulties SMEs encounter in transmitting reliable information about their real status and performance, so that it is difficult for lenders to ascertain if firms have the capacity to pay (risk of adverse selection) and/or the willingness to pay (risk of moral hazard) (Hyytinen and Väänänen, 2006).

In an attempt to reduce the inherent risk when granting credit to SMEs, banks seek to formalize both the information gathering process and the loan officer's decision process. Application forms are developed to standardize information gathering. Banks provide training to loan officers that conveys explicit criteria that should be used to determine the creditworthiness of the borrower (Bruns et al, 2008). Nevertheless, despite banks' efforts to homogenize the credit decision-making process, as De la Torre et al (2010, 2288) state, "SME ratings do not lead to the automatic approval of loans, but they rather provide the basis for the risk analyst to evaluate loans and decide on their approval". Thus, it is logical to assume that loan officers play a key role in producing and interpreting information, and therefore, personal, perceptual or psychological variables also matter in the credit granting decision (Toft, 2002; Scott, 2006).

In this context, this paper studies the effect of perceived default risk and accounting information quality on the loan officers' willingness to grant credit to SMEs. As far as we know, although empirical studies have shown the positive effect that information sharing has on the credit availability to SMEs (Love and Mylenko, 2003; 
Brown et al, 2009; Moro et al, 2014), there is no previous research that has adopted this approach for studying the effect of the perception of risk (which is one of the most frequent variables included in decision-making models) and information quality (which is the key factor in the reduction of information asymmetries) on the credit granting decision-making outcomes (both credit access and credit conditions).

Additionally, this study takes into account the possible effect of external audit because, as a control and supervision element of the information disclosed by companies, it could significantly affect the two perceptual variables included in the proposed research model. Previous research shows that the audited financial statements of smalls firms are crucial to the banks for making lending decisions (Berry et al, 1993; Cassar, 2011; Van Caneghem and Van Campenhout, 2012). There is also evidence that the desire to improve relationships with lenders is one reason why the directors choose to audit the annual accounts (Collis et al, 2004; Palazuelos et al, 2017).

Accordingly, from a questionnaire to 471 Spanish bank loan officers, this study provides three fundamental contributions with respect to the previous literature. Firstly, we examine the effect of perceived default risk and accounting information quality on credit granting decision-making for the first time. Secondly, we take into account both the loan officers' willingness to provide access to financing and to apply favourable conditions. Thirdly, we analyse whether there are differences in such process between SMEs that present audited financial statements and those that do not.

The remainder of this paper is structured as follows. In the second section, a theoretical revision of SMEs' access to credit is made, paying attention to the role of the above-mentioned variables, and justifying the proposed research hypotheses. In the third section, the methodology is explained. In the fourth section, the results are exposed. Finally, in the fifth section, the implications derived from the work, the limitations, and the future lines of research are set forth.

\section{Literature review and research hypotheses}

\subsection{SMEs' access to credit: The role of accounting information and auditing}

In high-income OECD economies, financial institutions are the most frequent source of new loans, since the structure of their financial system reflects a clear predominance of bank intermediation (Demirgüç-Kunt et al, 2015). However, often depending on the size of the organizations, there are significant differences in the funding that is obtained. In particular, there is huge evidence that SMEs are those who most frequently 
experience the phenomenon known as "credit rationing" (Cressy, 2002; Beck et al, 2005, 2006). This corresponds to a situation where the company does not obtain the required funds or only acquires them under worse conditions than expected (Stiglitz and Weiss, 1981; Casasola and Cardone, 2009).

The opaqueness generally attributed to SMEs, which accentuates information asymmetries, is one of the main arguments that justify the importance of size when it comes to obtaining external funding (Berger and Udell, 1998; Berger, et al, 2001; Hyytinen and Pajarinen, 2008). When considering whether to grant a loan, the natural response for a bank is to seek more information in order to reduce the uncertainty about the likelihood of loan repayment. However, it can be particularly challenging to collect information about SMEs. It is not unusual for small businesses to have a short history, a lack of formal or public records, or a deficiency of formal control systems (Bruns et al, 2008). This lack of information can put the banks at a disadvantage by making it difficult to differentiate between high-risk and low-risk borrowers (Stiglitz and Weiss, 1981; Berger and Udell, 1998). For that reason, lenders may demand more guarantees and increase the cost of debt. In some cases, lenders may not be willing to provide funding and will consequently deny credit.

Hence, the availability of different sources of information is an important valuation factor for credit granting decision-making. However, special attention should be given to accounting information, as the financial statements play a major role in the credit evaluation phase of the commercial loan decision (Libby, 1979; Danos et al, 1989). However, accounting information loses its utility if it does not meet a number of quality criteria that serve to allow a lender to make the most appropriate and suitable decisions at all times. That is, accounting information has to be as timely, accurate, complete, relevant, and reliable as possible to serve as a basis for making business and financial decisions (Avery et al, 1996; IASB, 2009). ${ }^{1}$

In that sense, audit reports that confirm or correct the data of the financial statements they accompany can contribute to the achievement of such an aim. In particular, the independent technical opinion they contain should help mitigate or placate information asymmetries between the companies and the financial groups to

\footnotetext{
${ }^{1}$ Section 2 of International Financial Reporting Standard for Small and Medium-sized Entities (IFRS for SMEs), published by the International Accounting Standards Board (IASB), establishes 11 qualitative characteristics (understandability, relevance, materiality, reliability, substance over form, prudence, completeness, comparability, timeliness, balance between benefit and cost, undue cost or effort) that financial information must gather. However, there are five dimensions that have been most frequently used to refer to 'information quality': timeliness, accuracy, completeness, relevance and reliability (see, among others, Monczka et al, 1998; Nicolaou and McKnight, 2006).
} 
which they relate, providing reliability and facilitating decision-making for users (Dechow et al, 2010; Guiral et al, 2014). In the context of credit granting, previous research shows that the audited financial statements of small firms are crucial for the banks in making lending decisions (Berry et al, 1993; Cassar, 2011; Van Caneghem and Van Campenhout, 2012). There is also evidence that the desire to improve relationships with lenders is one reason why directors choose to audit the annual accounts (Collis et al, 2004; Palazuelos et al, 2017).

\subsection{Perceived risk by banking decision-makers and credit granting to SMEs}

Bank lending decision is ultimately based on the estimation of the borrower's default risk (Norden and Weber, 2010). That is the chance that credit applicants will be unable to meet their obligations under the stipulated terms (repayment of principal and interests on the agreed timelines). In an attempt to minimize the probability of error, banks generally use several lending technologies to determine the likelihood of debt repayment (Berger and Udell, 2006): financial statement lending, asset-based lending, credit-scoring lending and relationship lending. In addition, they seek to formalize both the information gathering process and the loan officer's decision process (Bruns et al, 2008). However, despite all formal procedures to support the decision to grant credit, in many (or most) cases, it is ultimately based on the loan officer's judgment and perceptions (De la Torre et al, 2010). That's why many authors argue that behaviour is not conditioned by the objective risk, but by the impression or perception that individuals have of it (Bauer, 1960; Mitchell, 1999).

In general, perceived risk creates feelings of uncertainty, discomfort or anxiety (Dowling and Staelin, 1994), thus influencing the decision-making process (Siegrist et $a l, 2005)$. The studies available in the specific field of credit granting argue that when the risk associated to a company is potentially very high, banks may prefer to restrict their supply of funds, or apply more stringent financing conditions (Stiglitz and Weiss, 1981; Petersen and Rajan, 1994; Elsas and Krahnen, 1998). However, all of them have used proxies when trying to measure the expected risk, and no one have directly paid attention to loan officers' perceptions, even when they are who ultimately decide whether to grant credit or not, and under what conditions (De la Torre et al, 2010).

In accordance to that which was previously commented, the following hypotheses are set forth: 
H1. Loan officers-perceived default risk has a direct effect on their willingness to provide access to credit to SMEs.

H2. Loan officers-perceived default risk has a direct effect on their willingness to apply favourable credit conditions to SMEs.

\subsection{Perceived accounting information quality by banking decision-makers and credit granting to SMES}

It is well recognized that the information on financial statements varies a great deal in quality, ranging from highly accurate and reliable, to inaccurate and unreliable, to intentionally misleading (Dechow et al, 2010). Furthermore, SMEs are not required to publish the same quantity and quality of financial information as large companies. That is why acquiring and processing high-quality information are critical activities for decision-makers (Miranda and Saunders, 2003).

Previous literature (Boze 1988; Mitchell 1999) corroborates this point of view, in noting that the higher the level of perceived risk, the greater the need to look for higher levels of information as the best strategy to reduce the unknown factors and make a decision. However, the mere fact that there is a significant amount of information does not reduce another area of uncertainty, known as, in the words of DeJong and Smith (1984), the information risk. This is the risk associated with knowing whether the information is timely, accurate, complete, relevant, and reliable.

In particular, the perception that the information is high-quality should increase the likelihood that relationships will be developed in a more controlled manner, with less uncertainty and therefore with less perceived risk (Nicolaou and McKnight, 2006). Although this relationship has not been specifically tested in the context of credit granting, Fredriksson and Moro (2014) note that the more and the better the information collected, the better the position of the analyst to assess client and operation risks in the credit granting process, representing a lower overall risk of incurring future losses.

Following this reasoning, it is possible to propose the following hypothesis:

H3. Loan officers-perceived accounting information quality has a direct effect on their perception of SMEs' default risk.

Many studies consider that the key factor to accessing bank financing is the reduction of information asymmetries, which in turn depends on multiple factors, such 
as the length of the relationship (Petersen and Rajan, 1994), the closeness of the interaction between the loan manager and the SME's management (D'Auria et al, 1999), the bank's involvement in the firm's management (Elsas and Krahnen, 1998), or the physical distance between the lender and the borrower (Alessandrini et al, 2009). However, some believe that the information provided is the most important element for mitigating this conflict. In this sense, empirical studies (Love and Mylenko, 2003; Brown et al, 2009; Moro et al, 2014) have shown the positive effect that information sharing has on the credit availability to SMEs. In a more specific way, there are studies that show that the better the information is in terms of quantity and/or quality, the higher the likelihood is of accessing credit (Binks and Ennew, 1996) and obtaining more favourable credit conditions (Zecchini and Ventura, 2009; Moro et al, 2015). However, none of them focused specifically on accounting information, and did present some limitations. For example, Binks and Ennew (1996) only controlled for the willingness of the companies to provide information, Zecchini and Ventura (2009) used the number of employees as an indicator of creditor's ability to gain an insight into the firm's creditworthiness, and Moro et al (2015) only paid attention to the volume of the loan.

According to this evidence, the perception that the accounting information is high-quality will positively influence loan officers' willingness to facilitate SMEs' access to credit and apply favourable credit conditions. Consequently, the last two research hypotheses are proposed:

H4. Loan officers-perceived accounting information quality has a direct effect on their willingness to provide access to credit to SMEs.

H5. Loan officers-perceived accounting information quality has a direct effect on their willingness to apply favourable credit conditions to SMEs.

Figure 1 summarizes the theoretical model according to our research hypotheses.

[Figure 1 near Here] 


\section{Methodology}

\subsection{Measurement}

Quantitative research was carried out to test the above-mentioned hypotheses. Data was collected using a personal questionnaire, which included the following question areas: 1) the variables included in the research model (accounting information quality, perceived default risk, credit access, and credit conditions), measured separately for Audited and Not-audited SMEs; and 2) the socio-demographic and professional characteristics of respondents. The variables of the model were measured using multiitem instruments (7-point Likert and bipolar scales), which allowed us to obtain evaluations of psychological variables that cannot be quantified directly (Churchill and Iacobucci, 2002).

The scales were adapted from previous studies in order to ensure content validity (see Appendix 1). The scale for the measurement of the "credit access" variable is based on the works of Nicolaou and McKnight (2006) and Wagner et al (2011), assuming that the intention to continue with the relationship of exchange is similar to the intention to provide access to financing. In the scale of "credit conditions", the main variables that are applied in the credit policy have been included: volume granted, guarantees required, interest rates and other fees, and additional commissions. Likewise, "perceived default risk" was measured on a scale of five indicators based on the items proposed by Nicolaou and McKnight (2006), again adapted to the context of credit granting. Finally, the scale used to measure the "accounting information quality" was developed using the instrument proposed by Monczka et al (1998) and Nicolaou and McKnight (2006), which has been applied to analyse the quality of information in different contexts (supplier-buyer alliances and inter-organizational data exchanges, respectively).

\subsection{Sampling design}

The universe of the study is made up of Spanish bank loan officers with different levels of responsibility in credit granting decision-making, so that both employees of local bank branches and members of the Territorial Committees, or even of the Credit Operations Organs of the central offices, participated. The collaborating bank is specialized in the segments of SMEs, families, and self-employed, with branch offices throughout the whole national territory. In particular, 471 bank loan officers from 23 Spanish provinces answered the online questionnaire. In this sense, Spain represents a perfect case of study for being a developed country, with a high predominance of 
SMEs, of bank intermediation, and of credit restriction due to the financial crisis of 2008.

The collection of information was conducted through an online questionnaire. The respondents were presented a survey in which they were asked to value the items of each variable, first for companies with unaudited financial statements, and immediately after, for those with audited financial statements. Specifically, 1,069 emails were sent to bank loan officers, receiving a total of 471 valid responses, representing a response rate of $44.1 \%$.

Table 1 summarizes the socio-demographic and professional characteristics of the sample of loan officers used in the present investigation. Of the total number of participants, $66 \%$ were men and $34 \%$ were women, with a mean age of 44 years. Half of the sample had completed university studies, which shows the level of preparation that is generally required to work in the banking sector. In addition, the majority (86.4\%) occupy a position with local responsibility. This is also consistent with the hierarchical structure of financial institutions, where when the level of responsibility increases, the number of employees decreases. Moreover, credit granting operations to SMEs are mainly managed at a local level. Finally, respondents had worked in the sector for an average of approximately 20 years.

[Table 1 near here]

\subsection{Statistical analysis}

Before the results derived from these analyses can be explained, it is necessary to note that different strategies were used to avoid potential problems related to Common Method Variance (CMV) bias. The first strategy was the use of different types of measurement scales, as this can mitigate bias caused by the use of the same extremes in scales and anchoring effects (Podsakoff et al, 2003). In addition, the anonymity of the participants was guaranteed and it was indicated clearly in the introductory screen of the questionnaire that there were no right or wrong answers. That way we tried to reduce the level of fear and make the respondents less likely to edit their responses so that they were "socially desirable" or more in line with what they thought the researcher wanted them to answer (Chang et al, 2010).

Additionally, the Harman's single-factor test was conducted in IBM-SPSS software to check whether the correlation among variables was significantly influenced or not by their common source (Chang et al, 2010). The results of the analysis indicate 
that the items load into more than one factor, and that they are not concentrated in any one general factor. Consequently, this method also supports that CMV does not significantly influence this quantitative research.

Finally, it is important to point out that the questionnaire was sent to the bank loan officers twice. In the first round, 369 individuals responded, while 102 did it in the second. To test for non-response bias we compared the data of the first-round respondents with the data of the second-round respondents. The later respondents were considered as surrogates of non-respondents (Armstrong and Overton, 1977). The rationale is that non-respondents would be similar to late respondents based on factors such as lack of interest on the subject matter or the requirements of their jobs. The results of the comparison test between the earlier and later participants with respect to the background variables (gender, age, education, level of job responsibility, and years of experience) revealed that there are no statistical differences between the two groups.

The descriptive statistics of the variables are summarized in Appendix 1. In this sense, the average values obtained for all the items measured are clearly higher for the evaluation of Audited SMEs than for Not-audited SMEs, and T-Tests show that there are significant differences in the average values of all the items between Audited SMEs and Not-audited SMEs. Accordingly, decision-makers perceive that accounting information quality is higher and perceived default risk is lower in Audited SMEs. In addition, their valuations regarding their willingness to provide credit to SMEs and to apply favourable credit conditions are also better for those firms.

\section{Results}

A covariance-based SEM approach was followed for the estimation of the research model, using EQS 6.1 software. Firstly, the measurement model was estimated with confirmatory factor analysis (CFA) to test the psychometric properties of the measurement scales (reliability and validity). Next, the model was estimated in order to contrast the research hypotheses. Lastly, the effect of the control variable (Audited versus Not-audited SMEs) was tested through a multi-group analysis, in order to check if the relationships established in the research model were affected by whether the financial statements provided by the SMEs were audited or not.

\subsection{Estimation of the measurement model}

The results obtained for the goodness-of-fit indices show a correct specification for the measurement model, for both the cases of the Audited and Not-audited SMEs. In 
particular, there are three main classes of fit criteria: measures of absolute fit, measures of incremental fit, and measures of parsimonious fit (Hair et al, 2010). In this case, the statistics adopted are given by EQS 6.1, widely used in the SEM literature (Hair et al, 2010): Bentler-Bonett Normed Fit Index (BBNFI), Bentler-Bonett Non-Normed Fit Index (BBNNFI) and Root Mean Square Error of Approximation (RMSEA) for the measurement of overall model fit; Incremental Fit Index (IFI) and Comparative Fit Index (CFI) as measures of incremental fit; and Normed $\chi^{2}$ for the measurement of the parsimony of the model. The results summarized in Tables 2 and 3 confirm that, both for Audited and Not-audited SMEs, the BBNFI, BBNNFI, IFI, and CFI statistics clearly exceed the recommended minimum value of 0.9. RMSEA is located within the maximum limit of 0.08 , and normed $\chi 2$ takes a value clearly under the recommended value of 3.0 (Hair et al, 2010).

[Table 2 near here]

[Table 3 near here]

The reliability of the measurement scales was evaluated using Cronbach's Alpha, compound reliability and AVE coefficients (Bagozzi and Yi, 1988). The values of these statistics are, in every case, clearly above the required minimum values of 0.7 and 0.5 respectively (Hair et al, 2010), which supports the inner reliability of the proposed constructs (Tables 2 and 3). The convergent validity of the scales is also confirmed (Tables 2 and 3), since all items are significant to a confidence level of $95 \%$ and their standardized lambda coefficients are higher than 0.5 (Steenkamp and Van Trijp, 1991).

Discriminant validity of the scales was tested following the procedure proposed by Fornell and Larcker (1981), which requires comparison of the variance extracted for each pair of constructs (AVE coefficient) with the squared correlation estimate between these two constructs (Tables 4 and 5). In all cases the variances extracted for each construct are greater than the squared correlation between them, so the discriminant validity of the measurement scales is confirmed according to this method, both for Audited and Not-audited SMEs.

[Table 4 near here]

[Table 5 near here] 


\subsection{Estimation of hypothesized structural model}

Once the psychometric properties of the scales were adequately examined in the previous stage, the model was estimated using Robust Maximum Likelihood. This method avoids the problems related to non-normality of data by providing the outputs 'robust chi-square statistic' and 'robust standard errors', which have been corrected for non-normality (Byrne, 1994) and which consequently guarantees the validity of the model estimation. Figures 2 and 3 summarise the results for the estimation of the proposed research model both for Audited and Not-audited SMEs, indicating the goodness-of-fit indices of the structural model, $\mathrm{R}^{2}$ statistics for each dependent variable, and standardized coefficients for each relationship.

First, the results obtained confirm that perceived default risk by decision-makers has a direct effect on their willingness to provide access to credit and apply favourable conditions to SMEs, thus supporting hypotheses $\mathrm{H} 1$ and $\mathrm{H} 2$. In particular, a better perception about risk associated to SMEs leads to higher probability of granting credit to this type of firms, and implies better conditions in terms of larger amount of funding, reduced costs and commissions, and more limited warranties requirements. Additionally, according to our empirical evidence, the perception that accounting information is high-quality positively influences the perceived default risk by loan officers (H3), as well as the two variables concerning credit granting: credit access (H4) and credit conditions (H5). Therefore, perceived information quality has a direct effect on the outcomes of the relationship, and also an indirect effect through its influence on the risk perceived by bank loan officers. That way, perceived default risk becomes the central element of the process.

[Figure 2 near here]

[Figure 3 near here]

\subsection{Multi-group analysis: Audited vs. Not-audited SMEs}

A multi-group model was applied to analyse the potential differences in effects included in the research model (hypotheses H1 to H5) depending on whether the SMEs present their financial statements audited or not-audited. Specifically, the multi-group models allow analysis of the equality of the parameters considered in a structural model between different groups (Byrne, 1994). Thus, the multi-group models allow evaluation of the structural parameters for each sub-group, as well as compare the obtained value for each causal relation using the LM Test. In particular, the differences among groups 
using the statistics $\chi^{2}$ with a degree of freedom are analysed comparing the restricted and non-restricted models. The results of the multi-group analysis are summarized in Table 6.

[Table 6 near here]

The goodness-of-fit indexes of the multi-group model are clearly within the recommended values, confirming the fit of the model to data. The results from the Lagrange Multiplier test (LM test) show that there are no significant differences between the sub-groups of Audited and Not-audited SMEs (p-values > 0.01). This finding confirms the robustness of the research model proposed to explain the effect of perceived default risk and accounting information quality on credit granting decisionmaking, as the direction and intensity of the causal relationships are the same, independent of whether the SMEs presented their financial statements audited or notaudited. However, this does not mean that Audited and Not-audited SMEs are equally evaluated by loan officers, as the perceptions about risk and information quality are clearly better for the Audited SMEs, which results in a better willingness to provide credit access and apply favourable credit conditions.

\section{Conclusions}

This study analyses the effect of perceived default risk and accounting information quality on bank loan officers' decision to grant credit to SMEs. Additionally, this study takes into account the possible effect of external audit, given that an external auditor is expected to provide different stakeholders of the firm with independent assurance concerning the accuracy of the financial statements, the non-existence of financial statements fraud, and the going concern status, thus improving accounting information quality and lessening perceived default risk.

\subsection{Theoretical implications}

First of all, the results obtained in the research support the fact that perceived risk by loan officers is a key variable in bank lending processes, as it has a direct effect on loan officers' willingness to provide credit to SMEs and to do so in favourable credit conditions. In particular, a better perception of default risk associated to SMEs leads to higher probability of granting credit to this type of firms, and implies better conditions in terms of larger amount of funding, reduced interest rates and commissions, and more 
limited collateral requirements. Thereby, our findings support the perspective of previous studies that have argued that when the risk associated to a company is potentially very high, banks may prefer to restrict their supply of funds, or apply more stringent financing conditions (Stiglitz and Weiss, 1981; Petersen and Rajan, 1994; Elsas and Krahnen, 1998). However, we add to previous literature demonstrating that the lending decision is influenced not only by an "objective" measure of risk (such as bank ratings), but also by the perception that loan officers have of it.

Additionally, in accordance with the academic literature (Nicolaou and McKnight, 2006), this study supports that information quality positively influences the risk perceived by decision makers. That relationship had never been tested before in the specific context of credit granting.

Besides, it provides additional evidence to that obtained in other countries regarding the influence of information quality on credit access (Binks and Ennew, 1996), and credit conditions (Zecchini and Ventura, 2009; Moro et al, 2015). However, we specifically focus on accounting information, use a widely tested scale, ask directly to decision-makers and consider both the willingness to provide access to credit and a range of different credit conditions. That way, we propose a more complete research model, finding that perceived information quality has not only a direct effect on the outcomes of the relationship with banking stakeholders (credit access and conditions), but also an indirect effect through its influence on the bank loan officers' perception of default risk.

Furthermore, the direction and intensity of the causal relationships are the same, independent of whether the SMEs present their accounting information audited or notaudited, which confirms the robustness of the research model proposed. However, the perceptions about default risk and accounting information quality are clearly better for the Audited SMEs. That confirms that external audit is a key factor for lending decisions regarding SMEs (Berry et al, 1993; Cassar, 2011; Van Caneghem and Van Campenhout, 2012), but this time relying on first-hand information provided by the loan officers.

\subsection{Practical implications}

The results have interesting implications from an applied point of view, and especially for four different groups. 
Firstly, for SMEs that go to financial institutions in search of financing. On the one hand, it is essential that they are aware of the importance of presenting high-quality accounting information in order to increase loan officers' willingness to provide them credit and apply more favourable credit conditions. In that sense, it may be a motivation to hire an audit service voluntarily. On the other hand, in view of the importance that risk management can have to improve relationships with the stakeholders of the firm (financial institutions in this particular case), it may be interesting for many firms to create the position of a Chief Risk Officer (Karanja and Rosso, 2017), who can be in charge of risk control, risk management, and risk mitigation.

Secondly, for regulatory bodies, as some of the legal provisions on accounting and auditing are in line with reducing both the quantity and quality of information that SMEs are required to submit (for example, the increase in the thresholds for SMEs audit exemption; see Directive 2013/34/EU). However, with the present study, a clear call is made for greater consideration, since loan officers, who are one of the main users of SMEs financial statements, positively value high-quality accounting information and external audit services in the credit granting decision-making process.

Thirdly, for banks or financial institutions, as our findings show that lending relationships cannot be reduced to figures. Beyond a complete set of financial ratios or objective criteria, both perceived default risk and accounting information quality, two perceptual variables, influence and help the loan manager to make granting decisions regarding SMEs.

Fourthly, the obtained results may also be of interest to auditors, who can enhance the relevance and validity of their work based on the opinions revealed by bank loan officers, who are one of the main users of the financial statements and one of the most important stakeholders of SMEs. That is to say, they might take these findings as an argument to persuade SMEs of the desirability of hiring audit services voluntarily.

\subsection{Limitations and future lines of research}

To conclude, it is necessary to mention that in spite of the systematic methodology followed throughout the development of this study, the research that was carried out does present some limitations. On the one hand, it must be taken into account that the geographical scope of the study is limited to Spain, and that we just work with one financial institution. Anyway, Spain has similar characteristics to other European and OECD countries in terms of development, relevance of SMEs and bank intermediation. 
Furthermore, since the beginning of the crisis and throughout it, Spain has been used as a reference country for the study of the difficulties of SMEs and, in particular, for access to credit, so it can be considered an international benchmark. Additionally, the collaborating bank has a national implementation and has met the requirements set by the regulator for all entities in the sector, which makes it comparable to its competitors. Likewise, the high sample size reduces the possibility of bias. On the other hand, we focus on the loan officers' willingness to grant credit, which may not exactly match with their effective behaviour. In any case, decision-makers are faced very often with decisions on whether to grant credit, so it is likely that their responses to the survey reflect their perceptions and behaviour in past real situations. Moreover, loan officers' perceptions and intentions are very important indicators in order to understand the cognitive process underlying credit granting decision to SMEs.

Finally, based on the research carried out, it would be interesting to examine in future investigations the effect of other explanatory variables on the credit granting decision-making by loan officers, such as trust or the previous experience with the client, the business objectives set by the organization, and the general risk policy of the financial institution, among others. Regarding the auditing services, differences in valuations could be analysed, depending on whether they are provided by a Big 4 or a non-Big 4 firm. Furthermore, it would be interesting to extend the scope of the research to other potential users of the financial statements, such as companies that finance the internationalization of SMEs, public subsidy bodies, or suppliers of the firm. Additionally, it is worth mentioning the possibility of replicating this theoretical model in other countries with different economic, cultural, and legal characteristics, which could affect the valuations.

\section{References}

Alessandrini, P., Presbitero, A.F. and Zazzaro, A. (2009) Banks, distances and firms' financing constraints. Review of Finance 13(2): 261-307.

Armstrong, J.S. and Overton, T.S. (1977) Estimating nonresponse bias in mail surveys. Journal of Marketing Research 14(3): 396-402.

Avery, R.B., Bostic, R.W., Calem, P.S. and Canner, G.B. (1996) Credit risk, credit scoring, and the performance of home mortgages. Federal Research Bulletin 82: 621-648. 
Bagozzi, R.P. and Yi, Y. (1988) On the evaluation of structural equation models. Journal of the Academy of Marketing Science 16(1): 74-94.

Bauer, R.A. (1960) Consumer behavior as risk taking. In: D.F. Cox (ed.) Risk Taking and Information Handling in Consumer Behavior. Cambridge: Harvard University Press, pp. 389-398.

Beck, T., Demirgüç-Kunt, A. and Maksimovic, V. (2005) Financial and legal constraints to growth: Does firm size matter? Journal of Finance 60(1): 137177.

Beck, T., Demirgüç-Kunt, A., Laeven, L. and Maksimovic, V. (2006) The determinants of financing obstacles. Journal of International Money and Finance 25(6): 932952.

Berger, A.N. and Udell, G.F. (1998) The economics of small business finance: The roles of private equity and debt markets in the financial growth cycle. Journal of Banking \& Finance 22(6): 613-673.

Berger, A.N. and Udell, G.F. (2006) A more complete conceptual framework for SME finance. Journal of Banking \& Finance 30(11): 2945-2966.

Berger, A.N., Klapper, L.F. and Udell, G.F. (2001) The ability of banks to lend to informationally opaque small business. Journal of Banking \& Finance 25(12): 2127-2167.

Berry, A.J., Faulkner, S., Hughes, M. and Jarvis, R. (1993) Financial information, the banker and the small business. The British Accounting Review 25(2): 131-150.

Binks, M.R. and Ennew, C.T. (1996) Growing firms and the credit constraint. Small Business Economics 8(1): 17-25.

Boze, B.V. (1988) Selection of legal services: An investigation of perceived risk. Journal of Professional Services Marketing 3(1/2): 287-297.

Brown, M., Jappelli, T. and Pagano, M. (2009) Information sharing and credit: Firmlevel evidence from transition countries. Journal of Financial Intermediation 18(2): 151-172.

Bruns, V., Holland, D.V., Shepherd, D.A. and Wiklund, J. (2008) The role of human capital in loan officers' decision policies. Entrepreneurship Theory and Practice 32(3): 485-506.

Byrne, B.M. (1994) Structural equation modeling with EQS and EQS/Windows: Basic concepts, applications, and programming. Thousand Oaks, CA: Sage Publications. 
Casasola, M.J. and Cardone, C. (2009) "Too important to fail": Do banking relationships improve Spanish SMEs credit conditions?. Universia Business Review 24: 12-29.

Cassar, G. (2011) Discussion of the value of financial statement verification in debt financing: Evidence from private U.S. firms. Journal of Accounting Research 49(2): 507-528.

Chang, S.J., Van Witteloostuijn, A. and Eden, L. (2010) From the editors: Common method variance in international business research. Journal of International Business Studies 41(2): 178-184.

Churchill, G.A. and Iacobucci, D. (2002) Marketing Research Methodological Foundations. 8th ed. Mason: Thomson.

Collis, J., Jarvis, R. and Skerratt, L. (2004) The demand for the audit in small companies in the UK. Accounting and Business Research 34(2), 87-100.

Cosh, A. and Hughes, A. (1994) Size, financial structure and profitability: UK companies in the 1980s. In: A. Hughes and D.J. Storey (eds.) Finance and the Small Firm. London: Routledge, pp. 18-63.

Cressy, R. (2002) Introduction: Funding gaps. Economic Journal 112(477): F1-F16.

Danos, P., Holt, D.L. and Imhoff, E.A. (1989) The use of accounting information in bank lending decisions. Accounting, Organizations \& Society 14(3): 235-246.

D’Auria, C., Foglia, A. and Reedtz, P. M. (1999) Bank interest rates and credit relationships in Italy. Journal of Banking \& Finance 23(7): 1067-1093.

De la Torre, A., Martínez-Pería, M.S. and Schmuckler, S.L. (2010) Bank involvement with SMEs: Beyond relationship lending. Journal of Banking \& Finance 34(9): 2280-2293.

Dechow, P., Ge, W. and Schrand, C. (2010) Understanding earnings quality: A review of the proxies, their determinants and their consequences. Journal of Accounting and Economics 50(2): 344-401.

DeJong, D.V. and Smith, J.H. (1984) The determination of audit responsibilities: An application of agency theory. Auditing: A Journal of Practice \& Theory 4(2): 2034.

Demirgüç-Kunt, A., Klapper, L., Singer, D. and Van Oudheusden, P. (2015) The global findex database 2014: Measuring financial inclusion around the world. Policy Research Working Paper 7255. Washington: World Bank. 
Dowling, G.R. and Staelin, R. (1994) A model of perceived risk and intended riskhandling activity. Journal of Consumer Research 21(1): 119-134.

Elsas, R. and Krahnen, J.P. (1998) Is relationship lending special? Evidence from credit-file data in Germany. Journal of Banking \& Finance 22(10): 1283-1316.

Fornell, C. and Larcker, D. (1981) Evaluating structural equation models with unobservable variables and measurement error. Journal of Marketing Research 18(1): 39-50.

Fredriksson, A. and Moro, A. (2014). Bank-SMEs relationships and banks' riskadjusted profitability. Journal of Banking \& Finance 41: 67-77.

Guiral, A., Ruiz, E. and Choi, H.J. (2014) Audit report information content and the provision of non-audit services: Evidence from Spanish lending decisions. Journal of International Accounting, Auditing \& Taxation 23(1): 44-57.

Hair, J.F., Anderson, R.E., Tatham, R.L. and Black, W.C. (2010) Multivariate Data Analysis. 7th ed. New Jersey: Prentice Hall.

Hyytinen, A. and Pajarinen, M. (2008) Opacity of young businesses: Evidence from rating disagreements. Journal of Banking \& Finance 32(7): 1234-1241.

Hyytinen, A. and Väänänen, L. (2006) Where do financial constraints originate from? An empirical analysis of adverse selection and moral hazard in capital markets. Small Business Economics 27(4-5): 323-348.

IASB. (2009) International Financial Reporting Standard for Small and Medium-sized Entities (IFRS for SMEs). London, UK: IASC Foundation Publications Department.

Karanja, E. and Rosso, M.A. (2017) The Chief Risk Officer: A study of roles and responsibilities. Risk Management 19(2): 103-130.

Libby, R. (1979) The impact of uncertainty reporting on the loan decision. Journal of Accounting Research 17: 35-57.

Love, I. and Mylenko, N. (2003) Credit reporting and financing constraints. World Bank Mimeo.

Miranda, S.M. and Saunders, C.S. (2003) The social construction of meaning: An alternative perspective on information sharing. Information Systems Research 14(1): 87-107.

Mitchell, V. (1999) Consumer perceived risk: Conceptualisations and models. European Journal of Marketing 33(1/2): 163-195. 
Monczka, R.M., Petersen, K.J., Handfield, R.B. and Ragatz, G.L. (1998) Success factors in strategic supplier alliances: The buying company perspective*. Decision Sciences 29(3): 553-577.

Moro, A., Fink, M. and Kautonen, T. (2014) How do banks assess entrepreneurial competence? The role of voluntary information disclosure. International Small Business Journal 32(5): 525-544.

Moro, A., Fink, M. and Maresch, D. (2015) Reduction in information asymmetry and credit access for small and medium-sized enterprises. Journal of Financial Research 38(1): 121-143.

Nicolaou, A.I. and McKnight, D.H. (2006) perceived information quality in data exchanges: Effects on risk, trust, and intention to use. Information Systems Research 17(4): 332-351.

Norden, L. and Weber, M. (2010) Credit line usage, checking account activity, and default risk of bank borrowers. Review of Financial Studies 23(10): 3665-3699.

Palazuelos, E., Montoya, J. and Herrero, A. (2017) Determinants of the continuity in the voluntary demand for external auditing services: Evidence for the case of Spain. Spanish Accounting Review 20(1): 63-72.

Petersen, M.A. and Rajan, R.G. (1994) The benefits of lending relationships: Evidence from small business data. The Journal of Finance 49(1): 3-37.

Podsakoff, P.M., Mackenzie, S.B., Lee, J.Y. and Podsakoff, N.P. (2003) Common method biases in behavioral research: A critical review of the literature and recommended remedies. Journal of Applied Psychology 88(5): 879-903.

Scott, J.A. (2006) Loan officer turnover and credit availability for small firms. Journal of Small Business Management 44(4): 544-562.

Siegrist, M., Gutscher, H. and Earle, T.C. (2005) Perception of risk: The influence of general trust, and general confidence. Journal of Risk Research 8(2): 145-156.

Steenkamp, J.B.E. and Van Trijp, H.C. (1991) The use of LISREL in validating marketing constructs. International Journal of Research in Marketing 8(4): 283299.

Stiglitz, J.E. and Weiss, A. (1981) Credit rationing in markets with imperfect information. The American Economic Review 71(3): 393-410.

Toft, B. (2002) Financial risks, decisions and behaviour. Risk Management 4(1): 7-15. 
Van Caneghem, T. and Van Campenhout, G. (2012) Quantity and quality of information and SME financial structure. Small Business Economics 39(2): 341358.

Wagner, S.M., Coley, L.S. and Lindemann, E. (2011) Effects of suppliers' reputation on the future of buyer-supplier relationships: The mediating roles of outcome fairness and trust. Journal of Supply Chain Management 47(2): 29-48.

Zecchini, S. and Ventura, M. (2009) The impact of public guarantees on credit to SMEs. Small Business Economics 32(2): 191-206. 
Appendix 1: DESCRIPTIVE STATISTICS

\begin{tabular}{|c|c|c|c|c|}
\hline \multicolumn{2}{|c|}{$\begin{array}{l}\text { ACCOUNTING INFORMATION QUALITY (7- } \\
\text { point Likert scale): The information presented in the } \\
\text { AUDITED / NOT-AUDITED financial statements of } \\
\text { SMEs is... }\end{array}$} & $\begin{array}{l}\text { Average value } \\
\text { - Not-Audited }\end{array}$ & $\begin{array}{c}\text { Average value - } \\
\text { Audited }\end{array}$ & $\begin{array}{c}\text { Sig. } \\
\text { (bilateral) }\end{array}$ \\
\hline AIQ1 & Timely & 4.85 & 5.71 & $0.000 * * *$ \\
\hline AIQ2 & Accurate & 4.48 & 5.72 & $0.000 * * *$ \\
\hline AIQ3 & Complete & 4.36 & 5.77 & $0.000 * * *$ \\
\hline AIQ4 & Relevant & 4.83 & 5.79 & $0.000 * * *$ \\
\hline AIQ5 & Reliable & 4.25 & 5.80 & $0.000 * * *$ \\
\hline
\end{tabular}

*Sig. $<0.1$;* Sig. < 0.05; *** Sig. $<0.01$

\begin{tabular}{|l|l|c|c|c|}
\hline \multicolumn{2}{|l|}{$\begin{array}{l}\text { PERCEIVED DEFAULT RISK (7-point Semantic } \\
\text { differential scale): In general, credit granting to SMEs } \\
\text { that present AUDITED / NOT-AUDITED financial } \\
\text { statements means.. }\end{array}$} & $\begin{array}{c}\text { Average value } \\
\text { - Not-Audited }\end{array}$ & $\begin{array}{c}\text { Average value - } \\
\text { Audited }\end{array}$ & $\begin{array}{c}\text { Sig. } \\
\text { (bilateral) }\end{array}$ \\
\hline RSK1 & Maximum risk / Minimum risk & 4.20 & 5.02 & $0.000^{* * *}$ \\
\hline RSK2 & $\begin{array}{l}\text { Maximum potential for loss / Minimum } \\
\text { potential for loss }\end{array}$ & 4.27 & 5.02 & $0.000^{* * *}$ \\
\hline RSK3 & $\begin{array}{l}\text { Maximum probability of default / Minimum } \\
\text { probability of default }\end{array}$ & 4.32 & 5.02 & $0.000^{* * *}$ \\
\hline RSK4 & $\begin{array}{l}\text { Maximum probability of no recovery / } \\
\text { Minimum probability of no recovery }\end{array}$ & 4.33 & 5.06 & $0.000^{* * *}$ \\
\hline RSK5 & Minimum security / Maximum security $®$ & 4.26 & 5.03 & $0.000^{* * *}$ \\
\hline
\end{tabular}

${ }^{*}$ Sig. $<0.1$; ** Sig. $<0.05 ; * * *$ Sig. $<0.01$

\begin{tabular}{|c|c|c|c|c|}
\hline \multicolumn{2}{|c|}{$\begin{array}{l}\text { CREDIT ACCESS (7-point Likert scale): In general, } \\
\text { SMEs that present their financial statements } \\
\text { AUDITED / NOT-AUDITED... }\end{array}$} & $\begin{array}{l}\text { Average value } \\
\text { - Not-Audited }\end{array}$ & $\begin{array}{c}\text { Average value - } \\
\text { Audited }\end{array}$ & $\begin{array}{c}\text { Sig. } \\
\text { (bilateral) }\end{array}$ \\
\hline $\mathrm{ACC} 1$ & $\begin{array}{l}\text { Have a high probability that the bank makes } \\
\text { a positive assessment of their overall } \\
\text { position }\end{array}$ & 4.06 & 5.09 & $0.000 * * *$ \\
\hline ACC2 & $\begin{array}{l}\text { Have a high probability that the bank feels } \\
\text { predisposed to work with them }\end{array}$ & 4.10 & 5.17 & $0.000 * * *$ \\
\hline ACC3 & Have a high probability of getting funding & 4.09 & 5.11 & $0.000 * * *$ \\
\hline ACC4 & $\begin{array}{l}\text { Have a high probability that the bank wants } \\
\text { to establish long-term relationships with } \\
\text { them }\end{array}$ & 4.15 & 5.17 & $0.000 * * *$ \\
\hline
\end{tabular}

*Sig. <0.1; ** Sig. < 0.05; *** Sig. $<0.01$ 


\begin{tabular}{|l|l|c|c|c|}
\hline \multicolumn{2}{|l|}{$\begin{array}{l}\text { CREDIT CONDITIONS (7-point Likert scale): In } \\
\text { general, SMEs that present their financial statements } \\
\text { AUDITED / NOT-AUDITED... }\end{array}$} & $\begin{array}{c}\text { Average value } \\
\text { - Not-Audited }\end{array}$ & $\begin{array}{c}\text { Average value - } \\
\text { Audited }\end{array}$ & $\begin{array}{c}\text { Sig. } \\
\text { (bilateral) }\end{array}$ \\
\hline CON1 & $\begin{array}{l}\text { Have a high probability of accessing large } \\
\text { volumes of funding }\end{array}$ & 3.59 & 4.96 & $0.000^{* * *}$ \\
\hline CON2 & $\begin{array}{l}\text { Have a high probability of being charged } \\
\text { with reduced fees and commissions }\end{array}$ & 3.74 & 4.77 & $0.000^{* * *}$ \\
\hline CON3 & $\begin{array}{l}\text { Have a high probability of being charged } \\
\text { with low interest rates }\end{array}$ & 3.75 & 4.85 & $0.000^{* * *}$ \\
\hline CON4 & $\begin{array}{l}\text { Have a high probability of being required to } \\
\text { have limited guarantees/collateral }\end{array}$ & 3.94 & 4.64 & $0.000^{* * *}$ \\
\hline
\end{tabular}

*Sig. $<0.1 ; * *$ Sig. $<0.05 ; * * *$ Sig. $<0.01$ 
Table 1. Sociodemographic and professional profile of the sample

\begin{tabular}{|c|c|c|}
\hline \multirow{2}{*}{ Gender } & Male & $66 \%$ \\
\hline & Female & $34 \%$ \\
\hline Age (average) & \multicolumn{2}{|l|}{44 years } \\
\hline \multirow{5}{*}{ Education } & Professional training & $4.9 \%$ \\
\hline & Secondary & $8.9 \%$ \\
\hline & Mid-level University studies & $24.4 \%$ \\
\hline & High-level University studies & $50.1 \%$ \\
\hline & Postgraduate & $11.7 \%$ \\
\hline \multirow{3}{*}{ Level of job responsability } & Local & $86.4 \%$ \\
\hline & Regional & $10.6 \%$ \\
\hline & National & $3 \%$ \\
\hline $\begin{array}{l}\text { Years of experience in the } \\
\text { banking sector (average) }\end{array}$ & \multicolumn{2}{|l|}{20 years } \\
\hline
\end{tabular}


Table 2. Confirmatory factor analysis (Audited SMEs)

\begin{tabular}{|c|c|c|c|c|c|c|c|}
\hline Factor & Variable & \begin{tabular}{|c|}
$\begin{array}{c}\text { Standard. } \\
\text { Coef. }\end{array}$ \\
\end{tabular} & $\mathbf{R}^{2}$ & \begin{tabular}{|c} 
Cronbach's \\
$\alpha$ \\
\end{tabular} & $\begin{array}{l}\text { Composite } \\
\text { Reliability }\end{array}$ & AVE & $\begin{array}{c}\text { Goodness of fit } \\
\text { indices }\end{array}$ \\
\hline \multirow{4}{*}{ Credit Access } & ACC1 & 0.91 & 0.93 & \multirow{4}{*}{0.96} & \multirow{4}{*}{0.96} & \multirow{4}{*}{0.87} & \multirow{18}{*}{$\begin{array}{c}\text { BBNFI }=0.92 \\
\text { BBNNFI }=0.94 \\
\text { RMSEA }=0.06\end{array}$} \\
\hline & $\mathrm{ACC} 2$ & 0.93 & 0.86 & & & & \\
\hline & ACC3 & 0.94 & 0.89 & & & & \\
\hline & ACC4 & 0.95 & 0.90 & & & & \\
\hline \multirow{4}{*}{ Credit Conditions } & CON1 & 0.89 & 0.78 & \multirow{4}{*}{0.92} & \multirow{4}{*}{0.93} & \multirow{4}{*}{0.76} & \\
\hline & CON2 & 0.91 & 0.83 & & & & \\
\hline & CON3 & 0.93 & 0.86 & & & & \\
\hline & CON4 & 0.74 & 0.55 & & & & \\
\hline \multirow{5}{*}{$\begin{array}{c}\text { Perceived Default } \\
\text { Risk }\end{array}$} & RSK1 & 0.87 & 0.76 & \multirow{5}{*}{0.96} & \multirow{5}{*}{0.96} & \multirow{5}{*}{0.83} & \\
\hline & RSK2 & 0.91 & 0.82 & & & & \\
\hline & RSK3 & 0.96 & 0.91 & & & & \\
\hline & RSK4 & 0.94 & 0.89 & & & & \\
\hline & RSK5 & 0.88 & 0.78 & & & & \\
\hline \multirow{5}{*}{$\begin{array}{l}\text { Accounting } \\
\text { Information } \\
\text { Quality }\end{array}$} & AIQ1 & 0.86 & 0.74 & \multirow{5}{*}{0.96} & \multirow{5}{*}{0.96} & \multirow{5}{*}{0.82} & \\
\hline & AIQ2 & 0.94 & 0.88 & & & & \\
\hline & AIQ3 & 0.93 & 0.86 & & & & \\
\hline & AIQ4 & 0.93 & 0.86 & & & & \\
\hline & AIQ5 & 0.86 & 0.74 & & & & \\
\hline
\end{tabular}


Table 3. Confirmatory factor analysis (Not-audited SMEs)

\begin{tabular}{|c|c|c|c|c|c|c|c|}
\hline Factor & Variable & $\begin{array}{c}\text { Standard. } \\
\text { Coef. }\end{array}$ & $\mathbf{R}^{2}$ & $\begin{array}{c}\text { Cronbach's } \\
\alpha \\
\end{array}$ & $\begin{array}{l}\text { Composite } \\
\text { Reliability }\end{array}$ & $\overline{A V E}$ & $\begin{array}{c}\text { Goodness of fit } \\
\text { indices }\end{array}$ \\
\hline \multirow{4}{*}{ Credit Access } & ACC1 & 0.86 & 0.74 & \multirow{4}{*}{0.95} & \multirow{4}{*}{0.95} & \multirow{4}{*}{0.84} & \multirow{18}{*}{$\begin{aligned} \mathrm{BBNFI} & =0.94 \\
\mathrm{BBNNFI} & =0.96 \\
\mathrm{RMSEA} & =0.06\end{aligned}$} \\
\hline & ACC2 & 0.93 & 0.86 & & & & \\
\hline & ACC3 & 0.94 & 0.88 & & & & \\
\hline & ACC4 & 0.93 & 0.87 & & & & \\
\hline \multirow{4}{*}{ Credit Conditions } & CON1 & 0.84 & 0.70 & \multirow{4}{*}{0.88} & \multirow{4}{*}{0.89} & \multirow{4}{*}{0.68} & \\
\hline & CON2 & 0.91 & 0.84 & & & & \\
\hline & $\mathrm{CON} 3$ & 0.92 & 0.85 & & & & \\
\hline & CON4 & 0.58 & 0.34 & & & & \\
\hline \multirow{5}{*}{$\begin{array}{c}\text { Perceived Default } \\
\text { Risk }\end{array}$} & RSK1 & 0.84 & 0.71 & \multirow{5}{*}{0.96} & \multirow{5}{*}{0.96} & \multirow{5}{*}{0.82} & \\
\hline & RSK2 & 0.90 & 0.81 & & & & \\
\hline & RSK3 & 0.94 & 0.88 & & & & \\
\hline & RSK4 & 0.93 & 0.87 & & & & \\
\hline & RSK5 & 0.91 & 0.82 & & & & \\
\hline \multirow{5}{*}{$\begin{array}{l}\text { Accounting } \\
\text { Information } \\
\text { Quality }\end{array}$} & AIQ1 & 0.74 & 0.55 & \multirow{5}{*}{0.91} & \multirow{5}{*}{0.91} & \multirow{5}{*}{0.68} & \\
\hline & AIQ2 & 0.87 & 0.75 & & & & \\
\hline & AIQ3 & 0.83 & 0.69 & & & & \\
\hline & AIQ4 & 0.86 & 0.74 & & & & \\
\hline & AIQ5 & 0.81 & 0.65 & & & & \\
\hline
\end{tabular}


Table 4. Results of discriminant validity tests (Audited SMEs)

\begin{tabular}{|c|c|c|c|c|}
\hline & Credit Access & Credit Conditions & $\begin{array}{c}\text { Perceived Default } \\
\text { Risk }\end{array}$ & $\begin{array}{c}\text { Accounting } \\
\text { Information Quality }\end{array}$ \\
\hline Credit Access & $\mathbf{0 . 8 7 ^ { \mathrm { a } }}$ & & & \\
\hline Credit Conditions & $0.75^{\mathrm{b}}$ & $\mathbf{0 . 7 6}^{\mathrm{a}}$ & & \\
\hline $\begin{array}{c}\text { Perceived Default } \\
\text { Risk }\end{array}$ & $0.24^{\mathrm{b}}$ & $0.21^{\mathrm{b}}$ & $\mathbf{0 . 8 3}^{\mathrm{a}}$ & \\
\hline $\begin{array}{c}\text { Accounting } \\
\text { Information Quality }\end{array}$ & $0.25^{\mathrm{b}}$ & $0.17^{\mathrm{b}}$ & $0.19^{\mathrm{b}}$ & $\mathbf{0 . 8 2}^{\mathrm{a}}$ \\
\hline
\end{tabular}

${ }^{a}$ AVE coefficient

${ }^{\mathrm{b}}$ Squared correlation between pairs of latent variables 
Table 5. Results of discriminant validity tests (Not-audited SMEs)

\begin{tabular}{|c|c|c|c|c|}
\hline & Credit Access & Credit Conditions & $\begin{array}{c}\text { Perceived Default } \\
\text { Risk }\end{array}$ & $\begin{array}{c}\text { Accounting } \\
\text { Information Quality }\end{array}$ \\
\hline Credit Access & $\mathbf{0 . 8 4}^{\mathrm{a}}$ & & & \\
\hline Credit Conditions & $0.69^{\mathrm{b}}$ & $\mathbf{0 . 6 8}^{\mathrm{a}}$ & & \\
\hline $\begin{array}{c}\text { Perceived Default } \\
\text { Risk }\end{array}$ & $0.30^{\mathrm{b}}$ & $0.20^{\mathrm{b}}$ & $\mathbf{0 . 8 2}^{\mathrm{a}}$ & \\
\hline $\begin{array}{c}\text { Accounting } \\
\text { Information Quality }\end{array}$ & $0.18^{\mathrm{b}}$ & $0.11^{\mathrm{b}}$ & $0.20^{\mathrm{b}}$ & $\mathbf{0 . 6 8}^{\mathrm{a}}$ \\
\hline
\end{tabular}

${ }^{a}$ AVE coefficient

${ }^{\mathrm{b}}$ Squared correlation between pairs of latent variables 
Table 6. Multi sample analysis (Audited vs Not-audited SMEs)

\begin{tabular}{|c|c|c|c|c|}
\hline & $\begin{array}{l}\text { Standard. Coef } \\
\text { Audited SMEs }\end{array}$ & $\begin{array}{c}\text { Standard. Coef } \\
\text { Not-Audited SMEs }\end{array}$ & $\begin{array}{l}\text { LM Test } \\
\text { p-value }\end{array}$ & Goodness of fit \\
\hline H1: Perceived Def. Risk $\rightarrow$ Credit Access & 0.38 & 0.41 & 0.73 & \multirow{5}{*}{$\begin{array}{c}\mathrm{BBNFI}=0.93 \\
\mathrm{BBNNFI}=0.95 \\
\mathrm{RMSEA}=0.43 \\
\mathrm{IFI}=0.96 \\
\mathrm{CFI}=0.96 \\
\chi^{2} \text { Normado }=2.72\end{array}$} \\
\hline H2: Perceived Def. Risk $\rightarrow$ Credit Conditions & 0.36 & 0.36 & 0.52 & \\
\hline H3: Acc. Info. Quality $\rightarrow$ Perceived Def. Risk & 0.43 & 0.45 & 0.99 & \\
\hline H4: Acc. Info. Quality $\rightarrow$ Credit Access & 0.27 & 0.30 & 0.12 & \\
\hline H5: Acc. Info. Quality $\rightarrow$ Credit Conditions & 0.21 & 0.22 & 0.96 & \\
\hline
\end{tabular}


Figure 1. Research model

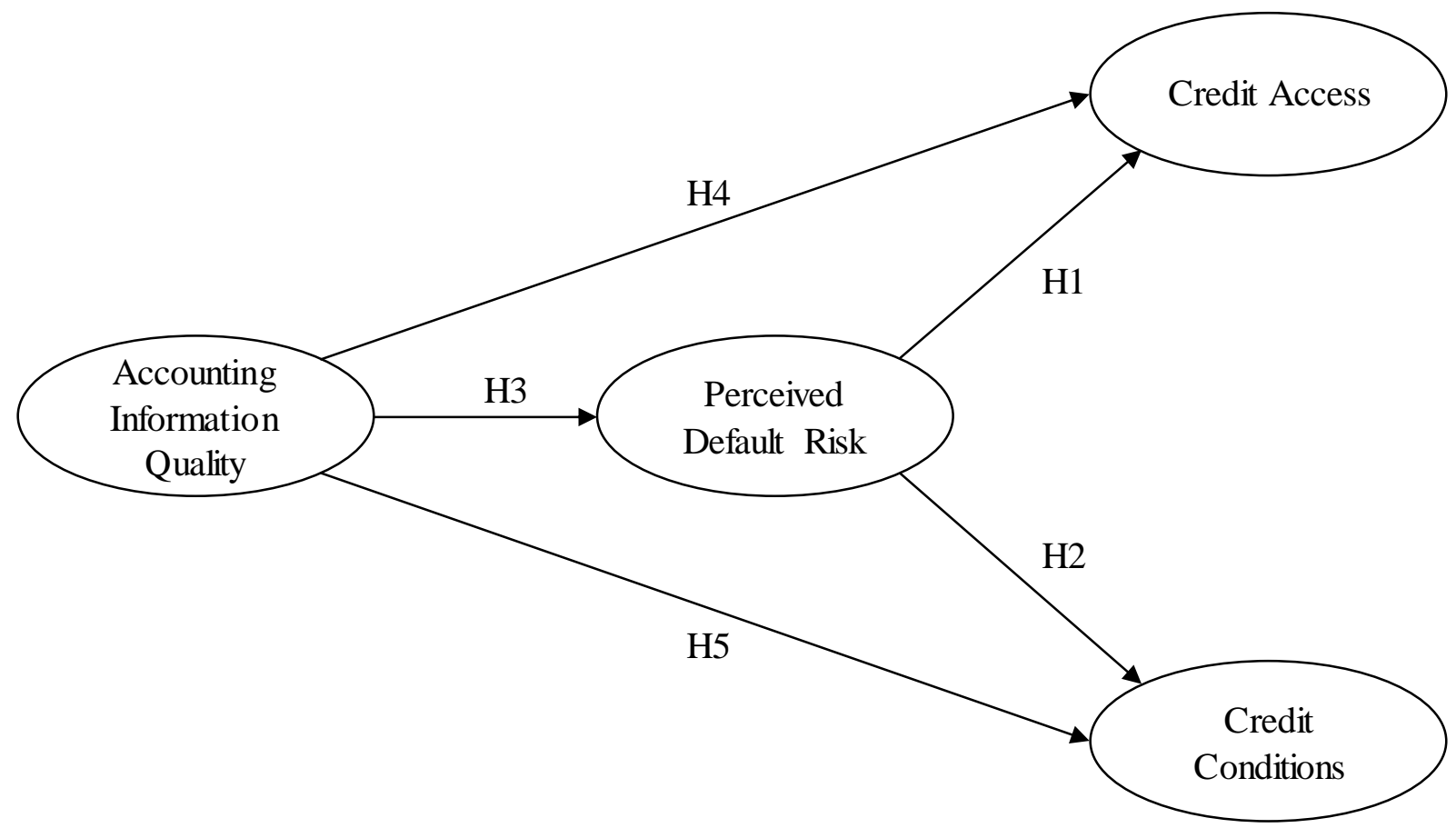


Figure 2. Structural model estimation - Audited SMEs

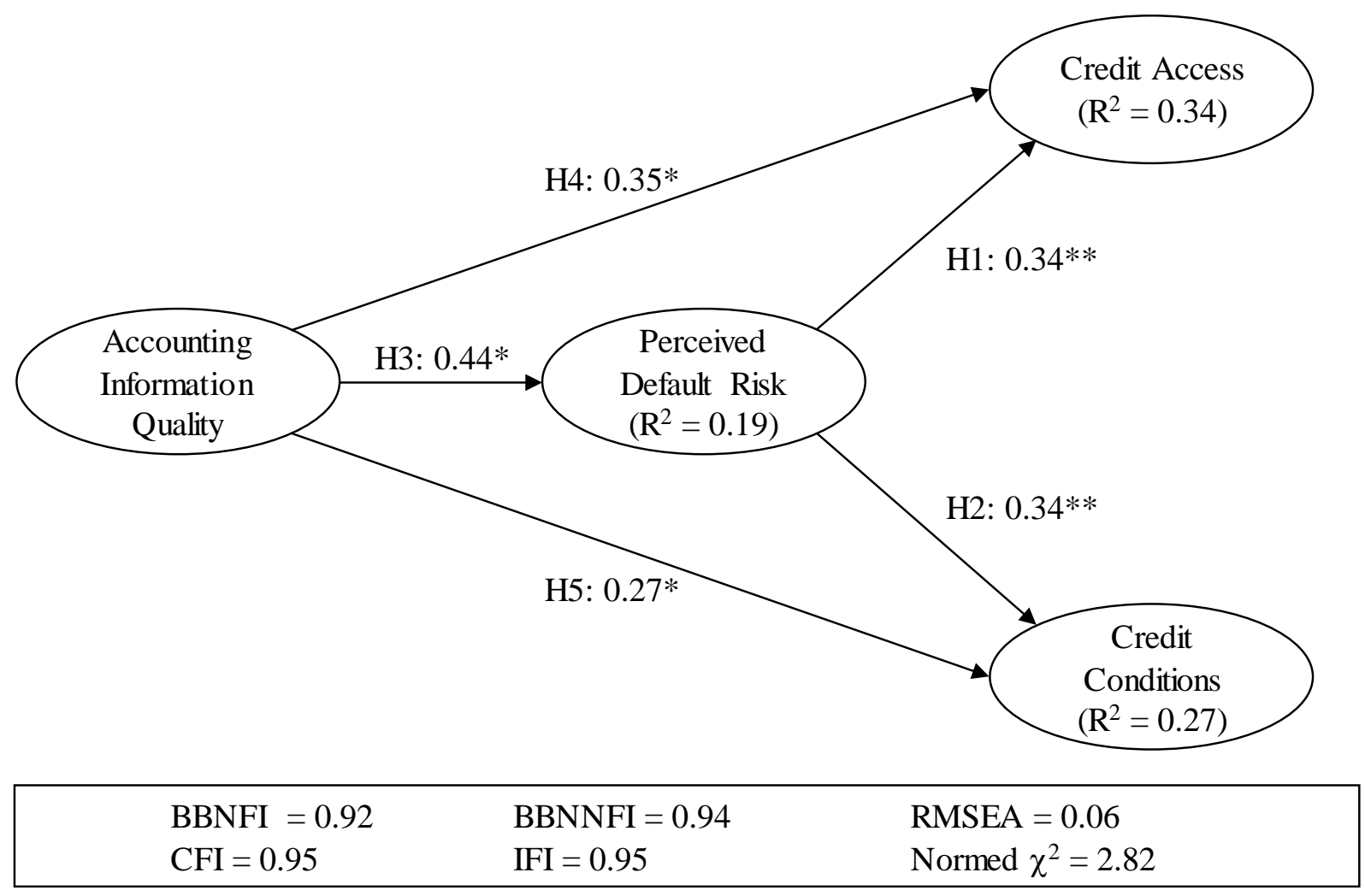

** Standardized coefficient and p-value $<0.05$ 
Figure 3. Structural model estimation - Not-audited SMEs

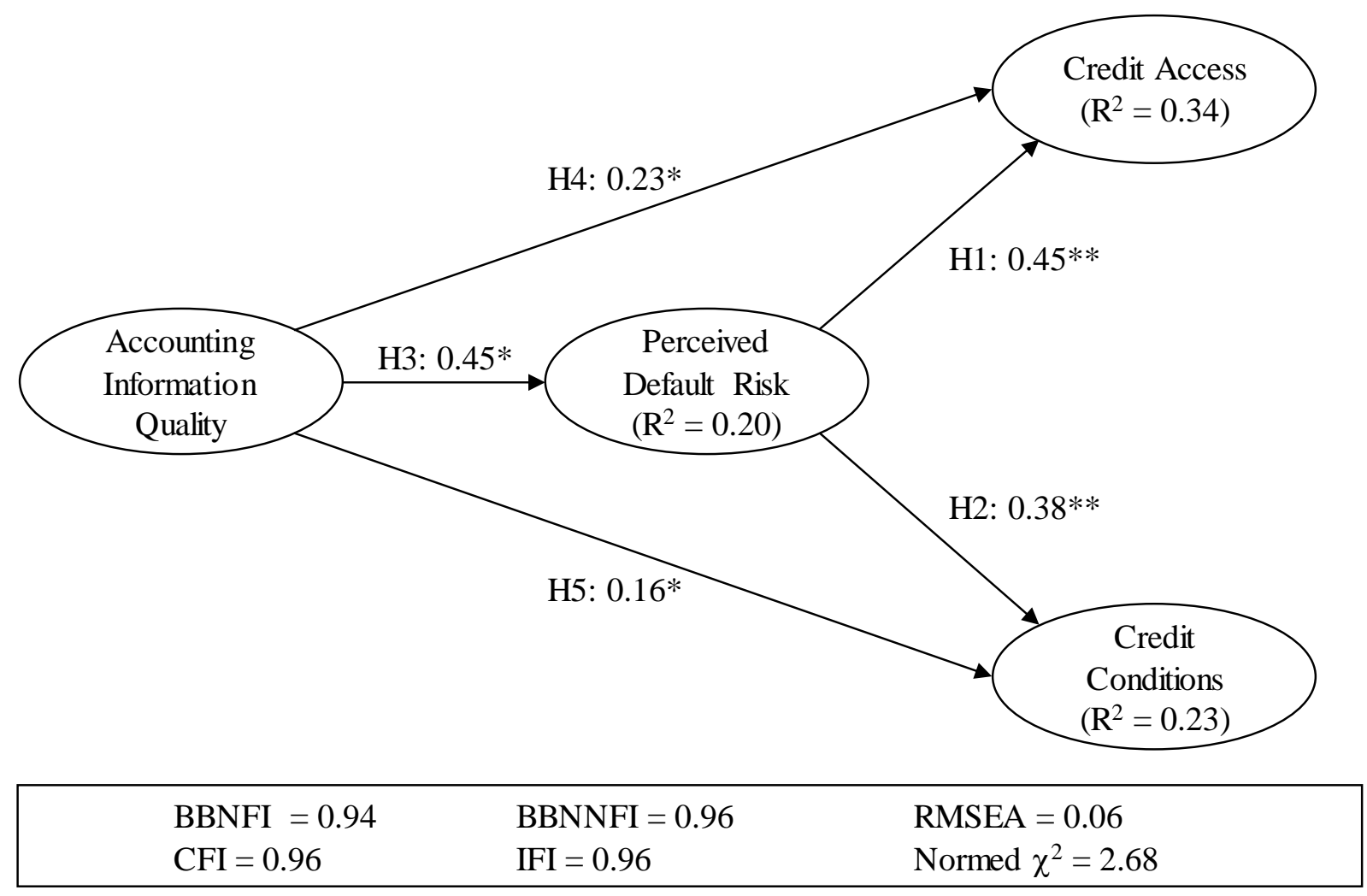

** Standardized coefficient and p-value $<0.05$ 